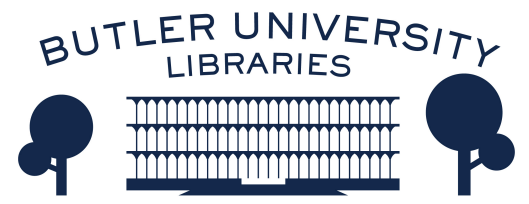

Journal of Hindu-Christian Studies

Volume 6

Article 19

January 1993

\title{
Book Review: "Exploring the Christian-Hindu dialogue: A Visit with Bede Griffiths and Russill Paul"
}

Shirley Embra

Follow this and additional works at: https://digitalcommons.butler.edu/jhcs

Part of the Religion Commons

\section{Recommended Citation}

Embra, Shirley (1993) "Book Review: "Exploring the Christian-Hindu dialogue: A Visit with Bede Griffiths and Russill Paul"," Journal of Hindu-Christian Studies: Vol. 6, Article 19.

Available at: https://doi.org/10.7825/2164-6279.1088

The Journal of Hindu-Christian Studies is a publication of the Society for Hindu-Christian Studies. The digital version is made available by Digital Commons @ Butler University. For questions about the Journal or the Society, please contact cbauman@butler.edu. For more information about Digital Commons @ Butler University, please contact digitalscholarship@butler.edu. 
salvation for the world and the Advaita teaching that knowledge of Brahman is all that is required. Clooney has not 'fudged' the tough question. But, even more to be admired, he does not leave it at the intellectual level only. After much patient reading, thinking and writing, the comparative theologian must go on to the practical experience of salvation or realisation (as the Advaitan would prefer to call it). The final goal is clearly soteriological or as a Hindu would put it the realisation of the yoga of knowledge. This is also why Clooney's project is theological rather than philosophical in nature. The chapter ends with a brief reflection on the requirements for the education of a comparative theologian.

Clooney conservatively calls this book an experiment in comparative theology. While not all experiments are successful, this one clearly is. This review has assumed considerable length due to the conviction of the reviewer that Clooney has moved us to a new paradigm for comparative study generally, and for theology in particular. This book needs to be read by theologians, Hindu and Christian, who wish to pursue their work in today's pluralistic context.
Clooney's experiment needs to be repeated by others using different texts, and the results compared. But, as Clooney warns, such work is demanding and requires much patient scholarly effort. In this, however, the approach proposed is not unlike the best science. Surely theologians and their students can be as dedicated as our colleagues in science - the potential goal may be as important as any scientific discovery. Frank Reynolds, in his Foreword (p. xvi) to the book puts it this way:

For theologians committed to a particular religious tradition, Theology After Vedanta opens a path toward a new kind of theology of religions. ... an inclusivist, comparatively oriented, potentially transformative theology of religions [that] could revitalise contemporary theological research and reflection not only in Christianity, but (with appropriate adaptations) in other religious traditions as well.

This is the single most important book I have read in a long while.

Harold Coward

University of Victoria

Victoria, Canada V8W 3P4

\section{Exploring the Christian-Hindu dialogue: $A$ Visit with Bede Griffiths and Russill Paul. 55 Minute VHS Video. VHS video $\$ 19.95$ (U.S.); audiotape from video $\$ 6.95$ (U.S.); available from Inner Growth Books and Videos, Box 520, Chiloquin, OR 97624 USA.}

\author{
BEDE GRIFFITH'S VISION of renewal in \\ the Church includes the formation of small \\ lay Christian contemplative communities in \\ the West, open to different religious \\ traditions, yet firmly grounded in their own \\ traditions. \\ In the first part of this video, Father \\ Bede responds to a series of carefully posed \\ questions concerning his life in India as a
}

Christian sannyasi and how he sees lay communities developing.

Of particular interest are his comments on topics such as the doctrine of the Trinity and his experience of Advaita, Christian versus Hindu mysticism, and the difference between an ashram and a monastery.

In the second part, Russill Paul, a professional musician born in the Anglo- 
Indian community of Madras, tells of his personal journey which led him to Father Bede's ashram where he spent five years. During that time music ceased to be a means of displaying technique and talent, and became for him an aid to contemplative expression. He is now exploring the possibility of creating contemplative communities in the United States which have their own identity and emphasis such as music. A description of the improvisational form of music he is developing is followed by an example.

This video demonstrates how one tradition can enrich another and lead to new forms of expression.

Shirley Embra 